\title{
Oxidative status of colitis-associated cancer model induced by azoxymethane /dextran sulfate sodium and the effects of COX-2 inhibitor in mice
}

\author{
Görkem KISMALI I,a, Aykut Göktürk ÜNER ${ }^{2, b}$, Öğünç MERAL ${ }^{1, c, ®}$, Merve ALPAY $^{3, d}$, \\ Berrin SALMANOĞLU ${ }^{1, \mathrm{e}}$, Dilek ÜLKER ÇAKIR ${ }^{4, \mathrm{f}}$, Funda KOSOVA ${ }^{5, \mathrm{~g}}$, Tevhide SEL $^{1, \mathrm{~h}}$
}

\begin{abstract}
${ }^{1}$ Ankara University, Faculty of Veterinary Medicine, Department of Biochemistry, Ankara; ${ }^{2}$ Adnan Menderes University, Faculty of Veterinary Medicine, Department of Physiology, Aydın; ${ }^{3}$ Düzce University, Faculty of Medicine, Department of Biochemistry, Düzce; ${ }^{4}$ Çanakkale Onsekiz Mart University, Faculty of Medicine, Department of Biochemistry, Çanakkale; ${ }^{5}$ Celal Bayar University, Department of Biochemistry, Manisa, Turkey. aORCID: 0000-0003-3414-4697; bORCID: 0000-0002-9242-8279; ' $O R C I D$ : 0000-0001-8813-4991; dORCID: 0000-0002-8782-9561; ' ORCID: 0000-0003-4344-5782; f ORCID: 0000-0002-8796-6363; gORCID: 0000-0001-8070-5067; hORCID: 0000-0002-9753-779.
\end{abstract}

${ }^{\top}$ Corresponding author: oguncmeral @ yahoo.com
Received date: 01.02.2019- Accepted date: 14.05 .2019

\begin{abstract}
Natural products and anti-inflammatory agents including cyclooxygenase-2 (COX-2) inhibitors which is a type of nonsteroidal anti-inflammatory drugs (NSAIDs) are highly considerable interest for the prevention of carcinogenesis. The objective of this study is to evaluate the oxidative status of colitis-associated cancer induced by azoxymethane (AOM)/dextran sulfate sodium (DSS), and the effects of COX-2 inhibitor in mice. Totally 40 mice were randomized and divided to four groups. All animals except control and Cox-2 inhibitor alone group received AOM/DSS to establish colitis-associated cancer model as reported elsewhere. COX2 preferential inhibitor meloxicam was used to minimize side effects such as gastrointestinal hemorrhage. Meloxicam were used $(5 \mathrm{mg} / \mathrm{kg}$, intraperitoneal) three times a week with meloxicam alone and AOM/DSS + meloxicam group. Superoxide dismutase (SOD), Glutathione peroxidase (GPx), Malondialdehyde (MDA) and Advanced Oxidation Protein Products (AOPP) which all of them are oxidative stress markers were measured by spectrophotometrically. The combination treatment of Meloxicam and AOM/DSS significantly increased $(\mathrm{P}<0.05)$ SOD activities in mice. GPx activities were found significantly increased $(\mathrm{P}<0.05)$ in Meloxicam and AOM/DSS combinations or alone. There were no differences between the control and treatment groups of MDA levels. AOPP levels of Meloxicam and AOM/DSS combination group were found higher than the other groups. Meloxicam and /or AOM/DSS treatment not caused lipid peroxidations, but increased the antioxidant enzymes and Advanced Oxidation Protein Products levels.

Keywords: Azoxymethane, colon cancer, COX-2, dextran sulfate sodium, oxidative stress.
\end{abstract}

\section{Farelerde azoksimetan /dekstran sülfat sodyum ile oluşturulan kolit ile ilişkili kanser modelinde oksidatif durum ve COX-2 inhibitörünün etkileri}

Özet: Anti-inflamatuar ajanlar, selektif siklooksijenaz 2 inhibitörleri ve doğal moleküllerin karsinogenezin önlenmesinde kullanılması önemli araştırma ve ilgi alanını oluşturur. Bu çalışmanın amacı, farelerde azoksimetan (AOM)/dekstran sülfat sodyum (DSS) ile oluşturulan kolit ile ilişkili kanser modelinde oksidatif durum ve COX-2 inhibitörünün etkilerini araştırmaktır. Toplam 40 fare rastgele olarak dört gruba ayrıldı. Kontrol ve COX-2 inhibitörü alan gruplar hariç bütün gruplar daha önce bildirilen yönteme göre AOM/DSS uygulanarak kolit ile ilişkili kanser modeli oluşturuldu. Gastrointestinal hemoraji gibi yan etkileri minimize etmek için COX-2 seçici inhibitörü meloksikam kullanıldı. Meloksikam $5 \mathrm{mg} / \mathrm{kg}$ dozda haftada üç kez i.p. olarak uygulandı. Oksidatif stres belirteçleri süperoksit dismutaz (SOD), glutatyon peroksidaz (GPx), malondialdehit (MDA) ve ileri oksidasyon protein ürünleri (AOPP) spektrofotometrik olarak ölçüldü. Meloksikam ve AOM/DSS birlikte uygulaması farelerde SOD aktivitesine önemli düzeyde yükseltmiştir $(\mathrm{P}<0.05)$. GPx aktivitesi meloksikam ve AOM/DSS tek ve kombine kullanımında önemli düzeyde artırmıştır $(\mathrm{P}<0.05)$. MDA düzeyinde konrol grubu ile diğer gruplar arasında fark bulunmamıştır. AOPP seviyesi ise, meloksikam ve AOM/DSS kombine kullanıldığı grupta diğer gruplara göre daha yüksek bulundu. Meloksikam ve/veya AOM/DSS uygulaması lipid peroksidasyonuna neden olmazken, antioksidan enzim ve AOPP değerlerini yükselttiği görüldü.

Anahtar sözcükler: Azoksimetan, COX-2, dekstran sülfat sodyum, kolon kanser, oksidatif stress. 


\section{Introduction}

Previous studies have shown that the activation of Arachidonic acid (AA) pathway plays an important role in the pathophysiological processes of inflammation and tumorigenesis (25). Membrane-released AA is immediately oxidized into the relatively unstable metabolite Prostaglandin G2 (PGG2), which is subsequently reduced to Prostaglandin $\mathrm{H} 2$ (PGH2) and both steps are catalyzed by the cyclooxygenase (COXs) enzymes. COX-1 and COX-2 are two important isoforms, but COX-2 is the most abundant isoform involving in various pathophysiological processes. Many tissues release COX-2 that are highly inducible by proinflammatory and mitogenic stimuli, including cytokines and growth factors (38). COXs and prostaglandin (PG) endoperoxide $\mathrm{H}$ synthases are critical enzymes of AA cascade and non-steroidal anti-inflammatory drugs (NSAIDs) and they have important functions in the inhibition of the production of primary prostanoids by leading to no access for AA to the active site of the cyclooxygenases (26).

The studies on the prevention of carcinogenesis strategies for colorectal cancer (CRC) are robust. Antiinflammatory agents including NSAIDs and selective COX-2 inhibitors have clinically been shown that they are promising and the most interesting candidates for the prevention of CRC. Additionally, some natural compounds have been reported as chemopreventive agent for $\operatorname{CRC}(1,11,20)$.

It is well-known that chronic inflammation is associated with the increased cancer risk in different diseases or disorders such as persistent hepatitis B, Helicobacter pylori infections, or an immunopathy which has the potential for the development of liver and gastrointestinal cancers. It has been reported that chronic inflammation leads to the development of malignancies worldwide at a ratio of $15 \%$. Thus, the association between inflammation and cancer rises the question of whether anti-inflammatory drugs such as NSAIDs can be used as antineoplastic treatment (21). Several NSAIDs have been discovered and still in use to relief the symptoms occurring in acute pain and chronic inflammatory diseases. Meloxicam is a NSAID which acts on COX-2 to inhibit the inflammation. In vivo and in vitro studies indicate that ability of meloxicam on the inhibition of COX-2 is more than on COX-1. Clinical studies showed that, meloxicam has good tolerability and less side effects (9).

Recently, number of evidence has demonstrated that oxidants or reactive oxygen species (ROS) are involved in the development of chronic inflammation and cancer (27). Indeed, tumor promoters have the ability to stimulate immune cells to generate ROS. Following an inflammatory stimulus, the initiation of carcinogenetic processes mediated by ROS may be due to the direct inflammatory stimulus. In addition of this, ROS can directly activate specific signaling pathways and thus lead to tumor development via the activation of cellular proliferation and angiogenesis as well as metastasis (31).

The objective of this study is to evaluate oxidative status of colitis-associated cancer model induced by azoxymethane (AOM)/dextran sulfate sodium (DSS) and effects of a COX-2 inhibitor, meloxicam, in mice.

\section{Material and Methods}

Animal model: Six-week-old BALB/c female mice $(\mathrm{n}=40)$ were housed five per cage under an environment with controlled temperature $\left(22 \pm 1{ }^{\circ} \mathrm{C}\right)$, and $12 \mathrm{~h}$ light/dark cycle. Mice were randomly divided to four groups; control group, AOM/DSS group, Meloxicam group and AOM/DSS Meloxicam group (Figure 1). All animal care and experimental procedures were approved by Adnan Menderes University, Ethical committee (Protocol number 64583101/2013/025).

\section{Azoxymethane (AOM)/dextran sulfate sodium (DSS) colorectal carcinogenesis animal model}

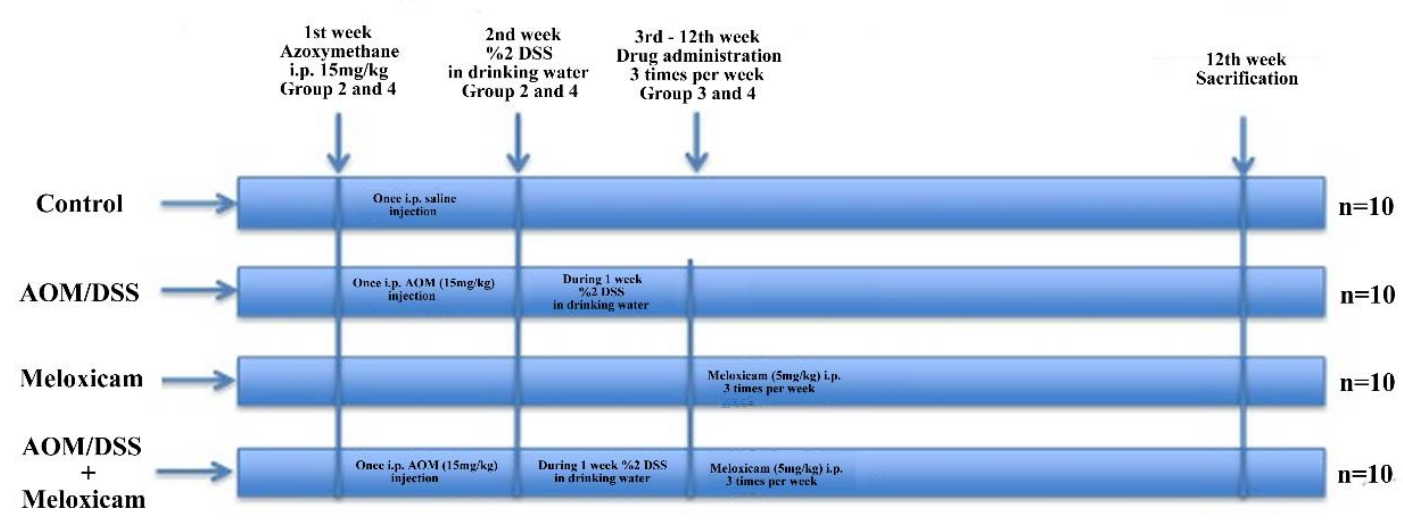

Figure 1. Experimental protocol for the colitis-associated colon carcinogenesis model. 
Induction of colon carcinogenesis, treatment with Meloxicam: Mice were injected with AOM $(15 \mathrm{mg} / \mathrm{kg}$, intraperitoneal) to induce colitis-associated colon carcinogenesis. After one week, mice were treated with $2 \%$ DSS (Sigma-Aldrich, USA) via drinking water for one week, followed by regular drinking water for recovery. Mice which were not treated with AOM/DSS, served as a negative control group. AOM/DSS group served as a positive control for colitis-associated colon carcinogenesis. Meloxicam and AOM/DSS Meloxicam groups were treated with Meloxicam at doses of $5 \mathrm{mg} / \mathrm{kg}$ at 3 times per week for 8 consecutive weeks, starting two weeks after the AOM injection. The overall experimental schedule is depicted in Figure 1.

Measurement of oxidative stress parameters: Blood samples were collected after sacrification and stored at $80^{\circ} \mathrm{C}$ until analyses. Plasma superoxide dismutase (SOD), malondialdehyde (MDA), advanced oxidation protein products (AOPP) levels and Glutathione peroxidase (GPX) activities were performed spectrophotometrically. SOD activities were determined using the SOD determination kit (Catalog no. 19160, Sigma-Aldrich, USA) according to the manufacturer's instructions. MDA levels was measured as a thiobarbituric acid (TBA) reactive substances with a spectrophotometer at $535 \mathrm{~nm}$ according to the method described by Yoshioka et al. (42). GPx activities were measured at $340 \mathrm{~nm}$ according to the procedure described by Paglia and Valentine (28). AOPP is a marker of oxidative modified proteins and consecutive inflammation and the method based on the reaction of AOPP with potassium iodide in an acidic medium. AOPP were measured at $340 \mathrm{~nm}$ and the values were expressed in $\mu \mathrm{mol} / \mathrm{mg}$ of protein (40). Plasma protein levels were determined by commercially available colorimetric assay kit (ERBA) using autoanalyzer (ERBA XL 600, Meinheim, Germany).

Statistical analysis: Statistical comparison between Meloxicam alone, AOM/DSS, Meloxicam and AOM/DSS and control groups were performed using one-way ANOVA with post hoc Duncan test. $\mathrm{P}<0.05$ were considered statistically significant.

\section{Results}

The combination treatment of Meloxicam and AOM/DSS significantly increased $(\mathrm{P}<0.05) \quad$ SOD activities (Table 1). GPX activities were found significantly increased $(\mathrm{P}<0.05)$ in mice treated with Meloxicam and AOM/DSS combinations or alone (Table 1). There were no differences between the control and treatment groups of MDA levels (Table 1). Advanced Oxidation Protein Products levels of Meloxicam and AOM/DSS combination group were found higher than the other groups $(\mathrm{P}<0.05)($ Table 1$)$.

\section{Discussion and Conclusion}

In developed countries, CRC is one of the most commonly diagnosed and extensively studied gastrointestinal cancers and one of the most leading cause of cancer death even though risk factors and pathologic mechanisms of CRC are well-known. The goals of cancer treatment are to prevent and eventually reverse the whole carcinogenic processes by natural or synthetic agents. Despite modern medical technology in oncologic therapy, cancer still remains the most common malignancy over the last decade $(16,30)$.

Meloxicam, a NSAID, selectively inhibits COX-2. COX-2 inhibitors may have the anti-tumoral effects by causing reductions in prostanoid and free radical synthesis, as well as by exerting changes in arachidonic acid metabolism via alternate metabolic pathways. One of the most common result of ROS production is inflammation, which plays important roles in the development of cancer. Several studies showed that selective COX-2 inhibitors might have been antitumor activity $(15,39)$.

Table 1. Plasma glutathione peroxidase (GPx), superoxide dismutase (SOD), malondialdehyde (MDA) and Advanced Oxidation Protein Product (AOPP) levels of control and study groups.

\begin{tabular}{|c|c|c|c|c|c|}
\hline Groups & $\mathbf{n}$ & GPx $(\mathrm{X} \pm \mathrm{SD})$ & $\operatorname{SOD}(\mathrm{X} \pm \mathrm{SD})$ & $\operatorname{MDA}(\mathrm{X} \pm \mathrm{SD})$ & $\operatorname{AOPP}(\mathrm{X} \pm \mathrm{SD})$ \\
\hline Control & 10 & $4.79 \pm 0.149^{\mathrm{a}}$ & $26.77 \pm 5.068^{\mathrm{a}}$ & $0.133 \pm 0.010^{\mathrm{a}}$ & $1.30 \pm 0.248^{\mathrm{a}}$ \\
\hline Meloxicam & 10 & $6.74 \pm 0.986^{\mathbf{b}}$ & $36.86 \pm 5.927^{\mathbf{a b}}$ & $0.130 \pm 0.024^{\mathrm{a}}$ & $1.47 \pm 0.346^{\mathrm{a}}$ \\
\hline AOM/DSS & 10 & $7.24 \pm 0.625^{\mathbf{b}}$ & $31.97 \pm 1.623^{\mathrm{ab}}$ & $0.108 \pm 0.022^{\mathrm{a}}$ & $1.15 \pm 0.140^{\mathrm{a}}$ \\
\hline AOM/DSS + Meloxicam & 10 & $9.35 \pm 0.924^{\mathbf{b}}$ & $42.53 \pm 1.687^{\mathbf{b}}$ & $0.125 \pm 0.030^{\mathrm{a}}$ & $2.66 \pm 0.260^{\mathbf{b}}$ \\
\hline
\end{tabular}

Data are presented as $($ Mean \pm SD). SD: Standard deviation. Statistical comparisons were performed using one-way ANOVA with post hoc Duncan test. P < 0.05 were considered statistically significant. (GPx : U/g of protein; SOD: U/g of protein; MDA: nmol/g of protein; AOPP: $\mathrm{nmol} / \mathrm{g}$ of protein). Different letters in the same column are statistically significant. 
Many pathways on the apoptotic effect of COX-2 inhibitors have been elucidated in colon carcinoma cells. Celecoxib, a COX-2 selective NSAID, partially induces apoptosis via a COX-2-dependent pathway. Maier et al. reported that celecoxib leads to an activation in caspases 3 and 9 together with cytochrome c release of colorectal carcinoma cells in humans (23). Sulindac and ibuprofen are other NSAID drugs. Studies showed that these drugs induce Bax and Bcl-XL expressions (44).

Dextran sulfate sodium (DSS) is a chemical that has direct toxic effects on the colonic epithelium and induces experimental colitis. The combination of DSS with AOM, which is a genotoxic agent, is a rapid, cheap and effective method for modeling CRC (34). According to Lee et al. the biological response to the AOM and DSS was different depending on the sex, showing more severely and earlier tumor incidence in male than female mice (22).

In the liver and colon, AOM is metabolized to a highly reactive methyl diazonium ion, eventually eliciting oxidative stress. During oxidative stress, the transcription of genes encoding antioxidant enzymes is activated and resulted in antioxidative responses characterized by the upregulation of antioxidative enzymes and a reduction in the sensitivity to the oxidative damage. Antioxidative enzymes have the beneficial effects in the attenuation of inflammatory damage and the neutralization of the ROS (32).

Antioxidant enzymes remove toxic intermediates that are generated when oxygen reduction is being occurred and thus they provide primary defense against the cytotoxic free oxygen species. As protective enzymes against lipid peroxidation in many tissues, beneficial roles of SOD, CAT and GPx are well-known. These enzymes are directly involved in the direct elimination of ROS which is one of the most powerful ways to prevent diseases and aging (7). Ashokkumar and Sudhandiran (2008) reported that SOD activity was lower in the mice treated by AOM compared to the control mice (3). In this study, we showed that treatment with Meloxicam increased SOD level in AOM/DSS induced colitis group.

Glutathione peroxidases, selenium-dependent enzymes, detoxify hydrogen peroxide and most of lipid hydroperoxides (36). Although more than twenty-five selenoproteins have been identified glutathione peroxidase (GPx), thioredoxin reductase $(\mathrm{TrR})$, and selenoprotein $\mathrm{P}(\mathrm{sel} \mathrm{P})$ play a role in antioxidative defense (18). A reduction in the activity of these antioxidant enzymes may result in an increase in oxidative stress and can cause damage to several biomolecules, preferentially DNA, which may further cause neoplastic transformation in the affected tissues $(5,13)$.

In vivo and in vitro studies have confirmed the anticarcinogenic effects of several selenoenzymes. Mice with impaired selenoprotein biosynthesis show more carcinogenesis in the prostate compared to the control mice (10). Overexpression of GPx-1 and selenium supplementation into the cultured carcinoma cells or normal fibroblasts attenuate induced by ultraviolet (UV) (4). GPx-4 overexpression inhibits the development of L929 fibrosarcoma cells and increases the sensitivity of angio-destructive treatment against to the B16-BL6 melanoma cells (14). Moreover, Thirupurasundari et al. (2009) demonstrated a reduction in the concentration of reduced glutathione (GSH) of rats with colon cancer induced by AOM compared to the control rats. Overall, GSH together with GPx and glutathione-S-transferase (GST) have important protective effects on cells in terms of cytotoxic and carcinogenic agents by scavenging ROS (35).

Little is known that there is an association between genetic differences in GPx and the development of neoplasia in colon as evidenced by increasing the risk of colorectal cancer in subjects with GPx-1 (P200L) polymorphism $(12,13)$.

In the intestine, SOD, GPx and catalase (CAT) are main antioxidant enzymes (45). To maintain homeostasis, cells can adapt to the changes in the oxidant and antioxidant species. Excessive generation of free radicals beyond the capacity of defense leads to failure of this homeostatic process (6).

Kochi et al were found significantly higher serum hydroperoxide levels which is a marker of oxidative stress, in the AOM/ DSS treated Kyoto Apc Delta (KAD) rats than in the control rats (19). For all that, KAD rats are susceptible to inflammation and have a significantly higher incidence, multiplicity and malignancy of colon tumors compared with their genetic control (41). Treated with AOM exhibited a reduction in the colon SOD activity and an increased in the colon MDA level, as reported by Tan et al (33). Pandurangan et al were observed an increased MDA levels of colon tissues in AOM/DSS induced mice. Enzymatic antioxidants, such as SOD, CAT and GPx were decreased in the colon tissues of AOM/DSS induced mice (29). Yu et al showed that ginseng effectively suppressed AOM/DSS induced proinflammatory cytokines activation (43).

Oxidative stress is related to the pathogenesis of colitis (24). Treatment with DSS decreased the activity of SOD and increased the MDA levels of colonic tissues (29).

In this study, female BALB/c mice were used and increased serum SOD and GPx activities were observed in AOM/ DSS-induced colitis. This may be because of the serum antioxidant responses occur in AOM/DSS induced colitis.

Previous studies showed that the difference in the mean plasma MDA levels between the group with ulcerative colitis and the controls was not significant (2, 
37). In the present study no differences were observed between the control and treatment groups of MDA levels. As a result, it can be said that Meloxicam and /or AOM/DSS treatment not caused lipid peroxidation.

It has been reported that AOPP can be used as a more suitable marker of oxidative stress compared to lipid derivatives (8). AOPP has also been demonstrated as an inflammatory marker and mediator in many diseases. AOPP is an indicator showing oxidative protein damage and it leads to an activation in monocytes (40). In the present study, meloxicam, a specific COX-2 inhibitor, increased AOPP level in chemically induced colitis group compare to other groups.

Alagozlu et al (2) reported that the plasma AOPP levels were not different in the patients with active ulcerative colitis compared to the patients with inactive ulcerative colitis and the control subjects. Khan and Rampal (17) reported that oral administration of meloxicam produces oxidative stress in rabbits, as indicated by their elevated MDA levels and alteration of various antioxidant parameters. Meloxicam yielded a prooxidative effect, because of the prolonged duration of drug administration. However, several studies have reported the ameliorating effect of meloxicam on oxidative stress.

In conclusion, the oxidative stress was prevented by increased antioxidant activity in mice with AOM/DSS induced colitis model. Antioxidant response due to increased SOD and GPx levels were observed in mice with AOM/DSS induced colitis model. As a result, it can be said that the serum oxidant / antioxidant balance shows a change in favor of antioxidants in mice with AOM/DSS induced colitis model. However, it is necessary to work at the tissue level to define the oxidant / antioxidant balance in the pathogenesis of colitis.

\section{Conflict of Interest}

The authors declared that there is no conflict of interest.

\section{References}

1. Aggarwal B, Prasad S, Sung B, et al (2013): Prevention and treatment of colorectal cancer by natural agents from mother nature. Curr Colorectal Cancer Rep, 9, 37-56.

2. Alagozlu H, Gorgul A, Bilgihan A, et al (2013): Increased plasma levels of advanced oxidation protein products (AOPP) as a marker for oxidative stress in patients with active ulcerative colitis. Clin Res Hepatol Gastroenterol, 37, 80-85.

3. Ashokkumar P, Sudhandiran G (2008): Protective role of luteolin on the status of lipid peroxidation and antioxidant defense against azoxymethane-induced experimental colon carcinogenesis. Biomed Pharmacother, 62, 590-597.

4. Baliga MS, Wang H, Zhuo P, et al (2007): Selenium and GPX-1 overexpression protect mammalian cells against
UV-induced DNA damage. Biol Trace Elem Res, 115, 227242.

5. Brigelius-Flohé R, Kipp A (2009): Glutathione peroxidases in different stages of carcinogenesis. Biochim Biophys Acta, 1790, 1555-1568.

6. Cerutti P, Ghosh R, Oya Y, et al (1994): The role of the cellular antioxidant defense in oxidant carcinogenesis. Environ Health Perspect, 102, 123-129.

7. Das U (2002): A radical approach to cancer. Med Sci Monit, 4, 79-92.

8. Davies MJ, Fu S, Wang H, et al (1999): Stable markers of oxidant damage to proteins and their application in the study of human disease. Free Radic Biol Med, 11-12, 11511163.

9. Del Tacca M, Colucci R, Fornai M, et al (2002): Efficacy and tolerability of meloxicam, a COX-2 preferential nonsteroidal anti-inflammatory drug. Clin Drug Investig, 22, 799-818.

10. Diwadkar-Navsariwala V, Prins GS, Swanson SM, et al (2006): Selenoprotein deficiency accelerates prostate carcinogenesis in a transgenic model. Proc Natl Acad Sci USA, 103, 8179-8184.

11. Fajardo AM, Piazza GA (2015): Chemoprevention in gastrointestinal physiology and disease. Anti-inflammatory approaches for colorectal cancer chemoprevention. Am J Physiol Gastrointest Liver Physiol, 309, 59-70.

12. Hansen RD, Krath BN, Frederiksen K, et al (2009): GPX1 Pro(198)Leu polymorphism, erythrocyte GPX activity, interaction with alcohol consumption and smoking, and risk of colorectal cancer. Mutat Res, 664, 13-19.

13. Haug U, Poole EM, Xiao L, et al (2012): Glutathione peroxidase tagSNPs: associations with rectal cancer but not with colon cancer. Genes Chromosomes Cancer, 51, 598605.

14. Heirman I, Ginneberge D, Brigelius-Flohé R, et al (2006): Blocking tumor cell eicosanoid synthesis by GP $x 4$ impedes tumor growth and malignancy. Free Radic Biol Med, 40, 285-294.

15. Hwang D, Scollard D, Byrne J, et al (1998): Expression of cyclooxygenase-1 and cyclooxygenase- 2 in human breast cancer. J Natl Cancer Inst, 90, 455-460.

16. Johnson JJ, Mukhtar H (2007): Curcumin for chemoprevention of colon cancer. Cancer Lett, 255, 170181.

17. Khan AM, Rampal S (2014): Effects of repeated oral administration of pazufloxacin mesylate and meloxicam on the antioxidant status in rabbits. J Am Assoc Lab Anim Sci, 53, 399-403.

18. Kim JH, Hue JJ, Kang BS, et al (2011): Effects of selenium on colon carcinogenesis induced by azoxymethane and dextran sodium sulfate in mouse model with high-iron diet. Lab Anim Res, 27, 9-18.

19. Kochi T, Shimizu M, Shirakami Y, et al (2015): Utility of Apc-mutant rats with a colitis-associated colon carcinogenesis model for chemoprevention studies. Eur $\mathbf{J}$ Cancer Prev, 24, 180-187.

20. Kraus S, Naumov I, Arber N (2013): COX-2 active agents in the chemoprevention of colorectal cancer. Recent Results Cancer Res, 191, 95-103. 
21. Kuper H, Adami HO, Trichopoulos D (2000): Infections as a major preventable cause of human cancer. $\mathrm{J}$ Intern Med, 248, 171-183.

22. Lee SM, Kim N, Son HJ, et al (2016): The effect of sex on the azoxymethane/dextran sulfate sodium-treated mice model of colon cancer. J Cancer Prev, 21, 271-278.

23. Maier TJ, Schilling K, Schmidt R, et al (2004): Cyclooxygenase-2 (COX-2)-dependent and -independent anticarcinogenic effects of celecoxib in human colon carcinoma cells. Biochem Pharmacol, 67, 1469-1478.

24. Meira LB, Bugni JM, Green SL, et al (2008): DNA damage induced by chronic inflammation contributes to colon carcinogenesis in mice. J Clin Invest, 118, 2516-2525.

25. Nakanishi M, Rosenberg DW (2013): Multifaceted roles of PGE2 in inflammation and cancer. Semin Immunopathol, 35, 123-137.

26. O'Banion MK (1999): Cyclooxygenase-2: molecular biology, pharmacology, and neurobiology. Crit Rev Neurobiol, 13, 45-82.

27. Ohshima H, Bartsch H (1994): Chronic infections and inflammatory processes as cancer risk factors: possible role of nitric oxide in carcinogenesis. Mutat Res, 305, 253-264.

28. Paglia DE, Valentine WN (1967): Studies on the quantitative and qualitative characterization of erythrocyte glutathione peroxidase. J Lab Clin Med, 70, 158-169.

29. Pandurangan AK, Ismail $\mathbf{S}$, Saadatdoust $\mathbf{Z}$, et al (2015): Allicin alleviates dextran Sodium sulfate- (DSS-) induced ulcerative colitis in BALB/c mice. Oxid Med Cell Longev, 2015, 1-13.

30. Renuka, Kumar S, Sharma B, et al (2015): $n$-3 PUFAs: an elixir in prevention of colorectal cancer. Curr Colorectal Cancer Rep, 11, 141-149.

31. Reuter S, Gupta SC, Chaturvedi MM, et al (2010): Oxidative stress, inflammation, and cancer: how are they linked? Free Radic Biol Med, 49, 1603-1616.

32. Sohn OS, Ishizaki H, Yang CS, et al (1991): Metabolism of azoxymethane, methylazoxymethanol and $\mathrm{N}$ nitrosodimethylamine by cytochrome P450IIE1. Carcinogenesis, 12, 127-131.

33. Tan BL, Norhaizan ME, Huynh K, et al (2015): Brewers' rice modulates oxidative stress in azoxymethane-mediated colon carcinogenesis in rats. World J Gastroenterol, 21, 8826-8835.
34. Thaker AI, Shaker A, Rao MS, et al (2012): Modeling colitis-associated cancer with azoxymethane (AOM) and dextran sulfate sodium (DSS). J Vis Exp, 67, e4100.

35. Thirupurasundari CJ, Padmini R, Devaraj SN (2009): Effect of berberine on the antioxidant status, ultrastructural modifications and protein bound carbohydrates in azoxymethane-induced colon cancer in rats. Chem Biol Interact, 177, 190-195.

36. Toppo S, Flohé L, Ursini F, et al (2009): Catalytic mechanisms and specificities of glutathione peroxidases: variations of a basic scheme. Biochim Biophys Acta, 1790, 1486-1500.

37. Tüzün A, Erdil A, Inal V, et al (2002): Oxidative stress and antioxidant capacity in patients with inflammatory bowel disease. Clin Biochem, 35, 569-572.

38. Wang D, Dubois RN (2006): Prostaglandins and cancer. Gut, 55, 115-122.

39. Watkins DN, Lenzo JC, Segal A, et al (1999): Expression and localization of cyclo-oxygenase isoforms in non-small cell lung cancer. Eur Respir J, 14, 412-418.

40. Witko-Sarsat V, Gausson V, Nguyen AT, et al (2003): AOPP-induced activation of human neutrophil and monocyte oxidative metabolism: a potential target for $\mathrm{N}$ acetylcysteine treatment in dialysis patients. Kidney Int, 64, 82-91.

41. Yoshimi K, Tanaka T, Takizawa A, et al (2009): Enhanced colitis-associated colon carcinogenesis in a novel Apc mutant rat. Cancer Sci, 100, 2022-2027.

42. Yoshioka T, Kawada K, Shimada T, et al (1979): Lipid peroxidation in maternal and cord blood and protective mechanism against activated-oxygen toxicity in the blood. Am J Obstet Gynecol, 135, 372-376.

43. Yu C, Wen XD, Zhang Z, et al (2015): American ginseng attenuates azoxymethane/dextran sodium sulfate-induced colon carcinogenesis in mice. J Ginseng Res, 39, 14-21.

44. Zhang L, Yu J, Park BH, et al (2000): Role of BAX in the apoptotic response to anticancer agents. Science, 290, 989992.

45. Zhu H, Li YR (2012): Oxidative stress and redox signaling mechanisms of inflammatory bowel disease: updated experimental and clinical evidence. Exp Biol Med (Maywood), 237, 474-80. 